\title{
Identity of adolescents and its dimensions in the relation to Mass media: philosophical-ethical reflections
}

\author{
[Identita adolescentov a jej dimenzie vo vzt’ahu k masmédiám: \\ filozoficko-etické reflexie]
}

Andrea Leskova - Michal Valco

\section{DOI: $10.18355 /$ XL.2017.10.03.26}

\begin{abstract}
Anotácia
V článku je prioritne analyzovaná otázka formovania identity adolescenta vo vzt’ahu k masmédiám, s osobitným zameraním na televíziu. Kl’účovým zámerom je na základe realizovaného výskumu (na vzorke 259 adolescentov-vysokoškolákov vo vekovom rozpätí 18-22 rokov) vedecky skúmat' súvislost' medzi formujúcou sa identitou adolescenta a socializačným pôsobením televízie; analyzovat to, ako adolescenti vnímajú televíziu a podnety ňou ponúkané pre sebareflexiu; a identifikovat' ich postoje $\mathrm{k}$ obsahovej ponuke televízie. Článok napokon vyúst'uje do eticko-filozofickej reflexie skúmaného fenoménu.
\end{abstract}

Kl'účové slová: identita, formovanie identity, adolescent, masmédiá, televízia

\section{Úvod}

Mediálne prostredie adolescentov podlieha neustálej zmene. Popri televíznom vysielaní sa rozmáhajú internetové médiá a na nich postavené sociálne siete, ktoré sú nielen miestom vysielania a prijímania mediálnych obsahov, ale aj priestorom pre kreovanie sociálneho statusu a sebavnímania jednotlivca. Ich domnelou výhodou je unikátna fluidnost' virtuálnych komunít a vol’né prepojenia ich členov, charakterizované „špecializovanými, inštrumentálnymi putami“ medzi jednotlivými členmi. (Jurova, 2017: 14). Televízia, napriek rozmachu nových elektronických médií, však nestráca na popularite. Je jedným z významných komunikačných prostriedkov súčasnej doby a (najmä vo svojej verejnoprávnej forme) predstavuje inštitucionalizovanú formu pôsobenia na deti, mládež i dospelých. Závery súčasných výskumov sa aj napriek odlišnej metodológii a stanovených ciel'ov zhodujú v tom, že televízia aj nad’alej disponuje výrazným potenciálom v ovplyvňovaní percipientov, vplývajúc na jeho „vnímanie“ sveta i seba samého a aktívne tým dotvárajúc vnímanie „,identity každého jednotlivca.“ (Pavlikova, 2017: 64). V našom výskume sme v tejto súvislosti aplikovali kvalitatívnu obsahovú analýzu na verbálne odpovede adolescentov na otázky uvádzané v empirickej časti. Zaujímalo nás, ako respondenti myslia o danej téme, čo v súvislosti s danou témou považujú za najpodstatnejšie a aké je ich východisková perspektíva. V tejto súvislosti sme sa nevyhli minimálnej miere kvantifikácie relevantných obsahových jednotiek. Úsilie nájst' platnú interpretáciu v kvalitatívnom výskume sme podporili tzv. quasi-štatistikou.

\section{Identita a osobnost' adolescenta}

Zrelá a zdravá identita je výslednicou faktorov v minulosti a prítomnosti vplývajúcich na jednotlivca bez striktne determinovanej budúcnosti. Nie je to niečo, čo je jedincovi dané a ostáva nemenné. Problém identity je dnes už relatívne komplexne teoreticky i výskumne pokrytý. $\mathrm{Z}$ množstva fundovaných odborníkov zaoberajúcich sa touto problematikou možno vyzdvihnút' koncepcie Ondrejkoviča (2004), Warringa (2008), taktiež i Meada (1967) a Goffmana (1990), ktoré súhrnne do značnej miery objasňujú 
proces, $\mathrm{v}$ rámci ktorého sa stávame sociálnymi bytost’ami, proces utvárania vedomia svojho ,ja“ v kontexte socializácie, ako i proces získavania schopnosti riadit' sa v interakcii s inými istými pravidlami. Ludská identita sa konštituuje prostredníctvom dialógu, komunikatívne. Preto aj vnímanie seba samého závisí od toho, ako jedinca vnímajú druhí, potrebné je teda uznanie poskytované či odopierané druhými. Je to práve komunitný kontext, vyznačujúci sa intenzívnou interpersonálnou interakciou, ktorý pomáha jednotlivcovi dosiahnut' „zrelost', ktorej produktom sú pozitívne životné výsledky." (Valcova et al., 2016: 100). Najmarkantnejšie to možno pozorovat' najmä vo vekovej skupine tzv. „emerging adults“ (teda adolescentov, postupne sa „formujúcich“ do dospelých jedincov). Svoju identitu neustále dotvárame v interakcii s inými l'ud'mi, je výsledkom porovnávania subjektívneho vnímania a objektívneho vnímania sveta inými l'ud'mi. Vývoj osobnosti musíme vždy chápat' vo vzt’ahu $\mathrm{k}$ sociálnemu prostrediu. V dôsledku jej inherentne dynamického charakteru identita nie je vopred daná samotnou existenciou jednotlivca, ale vzniká a utvára sa ako výsledok súhry rôznych sociálnych skúseností a biologických daností. Z filozofického hl'adiska súhlasíme so Žalcom (2011: 105), ktorý upozorňuje na potrebu „vyhýbat' sa extrémnym pozíciám v problematike identít: nihilistickej alebo neutralistickej na jednej strane a jej nekritického prijímania a skostnatenosti na strane druhej.“ Kompetentnejšími prístupmi v tejto otázke sa zdajú byt' prístupy „kritického realizmu a dialogického univerzalizmu“ (Žalec, 2011: 105), ktoré berú vážne psychobio-sociologické danosti l'udského ja (teda jeho kontingentný charakter), no nevzdávajú sa pritom dôrazu na jeho univerzálnu hodnotu a dôstojnost'.

Pomôct' mladému človeku autenticky si formovat' svoju identitu v rýchlo sa meniacom svete je pomerne t’ažkou, náročnou úlohou. Hoci je obdobie adolescencie síce kritickým a rizikovým vývinovým obdobím, je pre hl'adanie a formovanie identity obdobím rozhodujúcim. Adolescencia je prechodným obdobím prípravy na dospelost'. Zahŕňa vekové obdobie približne medzi 15. - 20. rokom, ale v súčasnosti sa stále viac diskutuje o jeho predlžovaní v podobe neskoršieho vstupu do sveta dospelých. Dominantným aspektom adolescentného obdobia je hl'adanie vlastnej identity- kto som, aký som, čím sa odlišujem od iných. Jednou z najvýznamnejších koncepcií v rámci skúmania identity je koncepcia Eriksona (1963), ktorý pozitívne východisko adolescencie vidí vo formovaní pevnej a celistvej osobnej identity a základ pre jej vytvorenie spočíva v záujme jedinca o svet, v túžbe po zmysluplnom mieste v spoločnosti. Pocit identity ja je podl'a neho vzrastajúcim presvedčením, že vnútorná totožnost' a súvislost', ktoré boli pripravené $\mathrm{v}$ minulosti, sú teraz porovnávané s totožnost'ou a súvislost'ou vlastného významu pre druhých, ako je to evidentné v zrejmom prísl'ube životnej dráhy. Negatívnym východiskom adolescencie je zmätok v rolách, konfúzia rolí.

\section{Rastúci vplyv mediálneho pôsobenia}

V súčasnej spoločnosti popri sociálnom prostredí má pri formovaní identity vel'ký význam i mediálne prostredie. Ako podotýka Jankova (2016), „médiá nie sú len pasívnou reflexiou, ale aktívnym faktorom utvárania skutočnosti.“ (Jankova, 2016: 94). Najmä v období adolescencie, kedy sa formuje a stabilizuje hodnotová hierarchia, zohráva mediálna realita $\mathrm{v}$ procese sebadefinovania jednotlivca podstatnú úlohu vzhl'adom na rôznorodost' ponúkaných modelov. Opodstatnenost' v tomto kontexte majú prezentované vzory v masmédiách. Podl’a Kačinovej (2006:109) sú tieto umelo vytvorené vzory na jednej strane úspešní, v niečom výnimoční jedinci, často predstavujúci nedosiahnutel'ný ideál. Alebo naopak, obyčajní l’udia, ktorí mladých prit’ahujú práve svojou „normálnost'ou“. V obidvoch prípadoch sú však dané modely prezentované prít’ažlivým spôsobom a pôsobia vel'mi lákavo ako materiál pre napodobenie. Vzhl'adom na uvedené sa naliehavou otázkou stáva podiel prezentácie ozajstných hodnôt $\mathrm{v}$ masmédiách $\mathrm{v}$ porovnaní $\mathrm{s}$ komerčne priorizovanými dielami 
a ponukami, ktoré prezentujú aj výslovne negatívne hodnoty. Súhrnne možno konštatovat', že otázka formovania identity adolescenta vo vzt'ahu k médiám (konkrétne i vo vzt’ahu k televízii) je parciálne obsiahnutá vo viacerých teoretických i výskumných zisteniach domácej i zahraničnej proveniencie. Relevantné odkazy na autorov zaoberajúcich sa danou problematikou uvádzame v empirickej časti.

\section{Empirický výskum: metódy a ciele}

V našom výskume sme ako základnú metódu získavania dát (na ktoré sa v štúdii odvolávame) využili autorský dotazník. Dáta z neho získané boli analyzované postupmi kvalitatívnej obsahovej analýzy. Ako rámcové výskumné otázky, prelínajúce sa sotázkami $\mathrm{v}$ autorskom dotazníku, boli stanovené nasledovné: 1 . V čom vidia adolescenti klady/prínos televízie? 2. V čom vidia adolescenti negatíva/záporný vplyv televízie? V rámci kódovacieho postupu sme výpovede respondentov segmentovali na jednotlivé prvky, kódovacie jednotky, ktorými boli slovo, slovné spojenie, čast' vety, hrdina, zdroj, a to vždy v závislosti od príslušnej kategórie. Významové jednotky sú zložené z pojmov, ktoré označujú jednotlivé udalosti, napr. javy, pocity, súdy (Miovsky, 2006: 228). Tie sme opísali pomocou stanovených kategórií uvedených v d’alšom texte.

$\mathrm{Na}$ základe obsahu písomných reflexií v súvislosti s otázkou $V$ čom vidia adolescenti klady/prínos televizie? sme zostavili štyri obsahové kategórie:

1. Televízia ako zdroj informácií (subkategórie: 1.a informovanie, 1.b rozvíjanie vedomostí)

2. Televízia ako zdroj zábavy (subkategórie: 2.a pobavenie, 2.b oddych/relax)

3. Televízia ako partner

4. Obmedzený/žiadny prínos televízie

V súvislosti s otázkou $V$ čom vidia adolescenti negatíva/záporný vplyv televízie? sme zostavili pät' obsahových kategórií:

1. Manipulácia (subkategórie: 1.a negatívne ovplyvňovanie, 1.b kvalita informácií, 1.c zbytočné/bezvýznamné informácie)

2. Strata času

3. Aspekt zdravia

4. Agresia, násilie

5. Negatívny vplyv na deti/mládež

\section{Vyhodnotenie empirického výskumu}

Pokial' ide o prvú výskumnú otázku, zaznamenali sme celé spektrum pohl’adov na klady, resp. prínos televízie. Najväčším prínosom televízie je jednoznačne pre adolescentov jej informačný aspekt, t. j. ponímanie televízie ako zdroja informácií, obrazu o svete a o udalostiach v ňom. Včas doručená, výstižná, promptná a užitočná informácia získava $\mathrm{v}$ posledných desat'ročiach na vážnosti. Táto tendencia sa odzrkadl'uje aj vo výpovediach respondentov. Nedostatok informácií, ako podotýka Vrabec (2012) vo výskume Mládež a médiá - Úroveň mediálnej gramotnosti mladých l'udi na Slovensku, už vôbec nie je problémom mladých l'udí v súčasnej globálnej spoločnosti. Tie majú totiž možnost' získat' z najrozličnejších zdrojov, v rôznej kvalite a v širokom spektre formátov. Z uvedeného výskumu vyplýva, že zo škály médií je pre mladých l’udí druhým najdôležitejším informačným médiom televízia. Čo sa týka osobitne kategórie vysokoškolákov, len $35 \%$ ju označuje za najdôležitejšie informačné médium. Dôležitosti televízie ako relevantného zdroja informácí́ konkurujú noviny $(43 \%)$, rádio $(45 \%)$ a internet $(77,7 \%)$ so svojou dominantnou pozíciou. Túto skutočnost' sme zaznamenali aj vo výpovediach adolescentov našej výskumnej vzorky, avšak najväčší prínos televízie je vo vnímaní adolescentov 
spojený predovšetkým s informačným aspektom. U adolescentov sa ponímanie televízie ako zdroja informácií objavuje najčastejšie stelevíznymi novinami a spravodajstvom. Takmer pre $1 / 2$ respondentov je vel'kým pozitívom televízie jej vzdelávací, náučný aspekt spojený s obohatením. Potenciál masmédií „zdvihnút' úroveň vedomia, rozšírit' intelektuálne obzory a ponúknut' skúsenosti presahujúce aktuálny stav myslenia“ zdôrazňuje aj Zasępa (2002: 337). Prepojenost' alebo konfrontáciu so študijným aspektom (pomoc pri štúdiu) adolescenti uvádzali len výnimočne, na rozdiel napr. od výsledkov vyššie prezentovaného výskumu mediálnej gramotnosti, ktoré poukazujú na popredné miesto (2. miesto) televízie ako najdôležitejšieho zdroja študijných informácií pre vysokoškolákov, i ked' opät' je zjavná preferencia internetu. Informovanost' a vzdelávanie sa začína preferovat' $\mathrm{v}$ tomto kontexte so stúpajúcim vekom jedincov. Prínos televízie v rovine informovanosti a vzdelávania bol u adolescentov, i ked' vel'mi sporadicky, spájaný aj so zdokonal'ovaním cudzieho jazyka, čo zrejme súvisí s kvantitou programov tohto druhu v rámci programovej štruktúry, ako i s možnost'ami adolescentov zdokonal'ovat' sa v cudzom jazyku napr. prostredníctvom on-line technológíi. Ďalej v tejto rovine niekol'ko adolescentov vyzdvihlo i potenciál televízie v rozvíjaní fantázie a kreativity a taktiež niekol'ko z nich ocenilo široké spektrum názorov prezentovaných $\mathrm{v}$ televízii a následnú možnost' konfrontácie s nimi. Podl'a očakávaní výpovede respondentov našej výskumnej vzorky naznačujú, že druhou najpočetnejšou kategóriou v diskurze o kladoch televízie je zábava. Schopnost' televízie potešit', pobavit', rozptýlit' prezentovali respondenti vo svojich výpovediach v takmer konštantnej podobe, súčasne aj s možnost'ou relaxu a oddychu. Uvedené zistenie možno uviest' do súvislosti s teóriou užívania a uspokojovania, podl'a ktorej jednou z potrieb príjemcov, ktorú si uspokojujú využívaním médií, je práve potreba nechat' sa bavit' a rozptyl'ovat', utiect' od bežných starostí, obáv a úzkosti a dopriat' si najrôznejšie druhy potešenia (Burton - Jirak, 2001; McQuail, 2007). Je však na mieste spomenút' aj isté riziko s vyhl'adávaním a preferenciou zábavy v televízii. Kriticky sa napr. k frontálnemu vstupu zábavy na nízkej úrovni do všetkých televíznych médií a k hladaniu zábavy namiesto pôžitku vyjadruje Žilková (2006).

Prínos televízie je vo vyjadreniach respondentov spojený aj s ponímaním televízie ako „interakčného“ partnera. TV ako výplň vol’ného času, prostriedok na zabíjanie nudy, kulisa, to sú aspekty viac či menej zdôrazňované respondentmi. Vysokú frekvenciu sledovania televízie v kontexte trávenia vol’ného času bez rozdielu pohlaví potvrdzujú napr. Lukšík a Hradileková (2000). Celkovo z väčšiny výskumných prác zameraných na miesto televízie v kontexte trávenia vol'ného času adolescentov vyplýva, že televízia poskytuje mladým l'ud’om jednoduchý a pohodlný spôsob trávenia vol’ného času spojený so zábavou, oddychom i sprostredkovaním informácií, ako sme už aj vyššie naznačili. Môžeme sa však stretnút' aj s prístupmi, ktoré zdôrazňujú nezáujem a pokles miery sledovanosti televízie adolescentmi. Adolescencia je obdobím, kedy sa sledovanie televízie prudko znižuje, a to hlavne z dôvodu, že predstavuje jednu zo zložiek domova, od ktorého adolescent cíti potrebu odpútat' sa (Sedova, 2007). Marshall et al. (2006) vo svojej systematickej recenzii vzhl'adom na dáta vzt'ahujúce sa na vek ukazujú, že sledovanie televízie počas adolescencie klesá, ale tí, ktorí sú „,̌astými užívatel'mi“"v mladom veku, majú väčší sklon zostat' častými užívatel'mi aj v neskoršom veku. Adolescenti v niektorých prípadoch uvádzali ako prínos televízie jej využívanie ako kulisy. Toto tvrdenie však býva často bagatelizované. Potešitel'ným zistením je, že televízia poskytuje aj spoločnú pôdu pre spoločne strávený čas, pre rozhovor, témy a diskusiu. Sledovanie televízie dávajú respondenti do súvislosti nielen s rodinou, ale aj so známymi a priatel'mi. V tomto zmysle možno pozitívne vnímat' vzájomnú prepojenost' televízie a interpersonálnej komunikácie. Na druhej strane je televízia pozitívne vnímaná ako náhrada za sociálny kontakt či možnost' úniku od nie vždy príjemnej reality. Môže to 
symbolizovat' vyššiu mieru kritickosti voči sebe i okoliu, hĺbavého uvažovania či osobnej neistoty, neschopnosti „zaradit’ sa“. Obsahové spracovanie odpovedí na prvú výskumnú otázku uzatvára indiferentný či negatívny diskurz o kladoch televízie. Dôvody, ktoré adolescenti proklamujú s obmedzeným či žiadnym prínosom televízie, spočívajú na základe ich vyjadrení v nízkej kvalite obsahovej ponuky, v nedostatku času na televíziu a v uprednostňovaní internetu pred televíziou. Čo sa týka negatív televízie v ponímaní adolescentov ( $\mathrm{v}$ kontexte našej druhej výskumnej otázky), najčastejšie uvádzaným negatívom je asi u 4/5 výskumného súboru manipulácia. Manipulácia vo výpovediach respondentov bola najčastejšie spájaná s negatívnym ovplyvňovaním a reklamou. Kriticky sa vyjadrovali ku kvalite informácií, najčastejšie zdôrazňovali nekorektnost', neobjektívnost', skreslenost', nepravdivost' a v konečnom dôsledku zbytočnost' a ohlupovanie nič neprinášajúcimi informáciami (príklad telenoviel, reality show). $\mathrm{V}$ tejto rovine je pozitívnym zistením, že u adolescentnej mládeže je aspoň čiastočne poodkryté a reflektované zákulisie manipulácie a manipulatívnych techník v masmédiách, ale súčasne treba skonštatovat', že tieto zistenia nič nevypovedajú o ich priamej odolnosti voči rozmanitým nástrahám zdiel'aných obsahov. Práve tu vidíme priestor pre mediálnu výchovu jednak $\mathrm{v}$ teoretickej rovine, ako i zmapovanie jej aplikačného výstupu a efektívnosti v rovine empirickej. V ponímaní $1 / 4$ adolescentov televízia figuruje ako prostriedok straty a plytvania času, času, ktorý by mohol byt' venovaný iným, prospešnejším činnostiam. Zo štúdie Motla (Motl et al., 2006: 19-32) vyplýva, že pokles času stráveného sledovaním televízie súvisel $\mathrm{s}$ nárastom frekvencie vol’nočasových fyzických aktivít. Autori konštatovali vel'ký význam tohto vzt’ahu bez ohl'adu na pohlavie, socioekonomický status, fajčenie a hodnotu, ktorú účastníci výskumu prikladali zdraviu, vzhl'adu a úspechu. Zaujímavú a pestrú škálu výpovedí ohl'adom negatív televízie sme zaznamenali $\mathrm{v}$ súvislosti $\mathrm{s}$ aspektom zdravia. Najčastejšie respondenti uvádzali nadváhu, obezitu spojenú s nedostatkom pohybu, ako i negatívny vplyv na psychiku človeka. Sporadicky je reflektovaná i lenivost' a pasivita. Nadmerné sledovanie televízie ide vždy na úkor pohybu, ktorý má o. i. aj priaznivé účinky na duševnú rovnováhu človeka.

Závery štúdie Hancoxa et al. (2004: 257-262) dokumentujú súvis sledovania televízie $\mathrm{v}$ detstve a adolescencii s nadváhou, slabou kondíciou, fajčením a zvýšeným cholesterolom v dospelosti. Náklonnost' a závislost' na televízii je tiež premietnutá vo výpovediach respondentov. Burton a Jirák (2001) napriek pochopitel’ným obavám napr. ohl'adom nadmerného času venovaného sledovaniu televízie, vyzdvihujú u dospievajúcich mladých l’udí vysokú selekciu. Dospievajúci sa sústredia na svoj kultový program, o ktorom potom živo diskutujú, ale nerobí im t’ažkosti vypnút' televízor a dat' prednost' spoločnosti vrstovníkov. Podl'a pohl'adu adolescentov je jedno z najvýraznejších negatív televízie jej negatívny vplyv na deti a mládež. Je druhou najpočetnejšou kategóriou, obsahovo sa prelína výpoved’ami takmer polovice súboru adolescentov. Adolescentmi zdôrazňovaný negatívny vplyv televízie predovšetkým na deti konvenuje s vymedzením diváckej rizikovej skupiny Suchého (2007: 38), ktorý, odvolávajúc sa na hl'adisko vývojovej psychológie, konštatuje, že s najväčšou pravdepodobnost'ou budú zobrazovaným násilím alebo všeobecne nadmerným sledovaním televízie ohrozené deti mladšie ako 12 rokov. Natíska sa ale otázka, či adolescenti takto proklamovaným vplyvom televízie na deti nepodceňujú tento vplyv vo vzt’ahu k sebe. Oporu možno nájst' v mediálnom jave nazvanom efekt tretej osoby. Odborníci v oblasti komunikácie hovoria o všadeprítomnom efekte tretej osoby vtedy, ked' l'udia vnímajú médiá ako to, čo ovplyvňuje viac tých ostatných ako ich samých (Duck et al., 1999). Často zdôrazňovaným negatívom televízie je tiež pre $1 / 3$ vzorky adolescentov násilie a agresia. Prepojenie zobrazovania násilia a agresie 
$\mathrm{v}$ masmédiách (najmä $\mathrm{v}$ televízii) a následného agresívneho správania $\mathrm{v}$ reálnom živote je predmetom diskusie na všeobecnej i odbornej úrovni a ako sme sa už zmienili, stále zostáva otvorenou otázkou potvrdenie pôvodu i smeru tohto prepojenia.

\section{Závery}

Na základe vyššie prezentovaných zistení možno konštatovat', že existuje všeobecná súvislost' medzi formujúcou sa identitou adolescenta a socializačným pôsobením masmédií/televízie. Nakol'ko vplyv televízie nemožno skúmat' izolovane od ostatných faktorov vplyvu (či už ide o preferencie, motívy, potreby, poznatky, vlastné skúsenosti apod.), je zložité jednoznačne určit', v akej miere televízia vstupuje, resp. zasahuje do procesu formovania identity adolescenta. V našich prezentovaných výsledkoch sa premieta individuálna skúsenost' adolescentov i charakteristiky príznačné pre toto vekové obdobie. Podotýkame, že platnost' výsledkov je vzt’ahovaná predovšetkým $\mathrm{k}$ výberovému súboru adolescentov, účastníkov/účastníčok realizovaného výskumu, no má aj implikácie pre všeobecnejšiu reflexiu.

Vzhl'adom na to, že televízia patrí $\mathrm{k}$ najvplyvnejším médiám pôsobiacich na úroveň a obsah vedomia mladého človeka a formujúcich jeho identitu, je primárne dôležité identifikovat' roviny a oblasti jej vplyvu, ako i rozpoznat' základné mechanizmy a určujúce techniky jej pôsobenia. Z praktického hladiska považujeme za prioritné cielené formovanie predmetu mediálna výchova $\mathrm{v}$ rámci edukačných procesov na všetkých vekových úrovniach, osobitne u adolescentov. Primárnu úlohu v pôsobení na adolescentov však zohrávajú predovšetkým rodičia, ktorí sú zodpovední nielen za to, aký mediálny obsah a v akom rozsahu sa $\mathrm{k}$ adolescentom dostáva, ale aj za primeranú formu komunikácie a vytváranie zámerného priestoru na spoločné kritické uvažovanie o mediálnych obsahoch a posolstvách s adolescentmi. (Pala, 2015: 55). V opačnom prípade sa adolescenti potenciálne stanú l'ahkou korist'ou manipulácie nielen zo strany vtieravého reklamného priemyslu, zavádzajúcich správ, ale aj extrémistických skupín. (Slivka, 2017: 56-57). Znižuje sa aj ich schopnost' autentického, spoločenkopolitického angažovania sa v danej spoločnosti, ked’že nie sú schopní kriticky rozlišovat' medzi rozporuplnými politickými heslami a sloganmi (najmä vo forme politickej reklamy). Vo všeobecnosti pritom platí, že ked’že „moderné technológie [vrátane tých mediálnych] nie sú singulárnou mocou jednotlivca, ale skôr kolektívnou mocou spoločnosti, etický imperatív by mal nadobudnút podobu politického riešenia“". (Turcan, 2017: 37).

Apelujeme tiež na sebareflexiu tvorcov televíznych programov, v celkovej programovej štruktúre tohto audiovizuálneho média. Niet pochýb, že z marketingového hl'adiska je sledovanost' rozhodujúcim prvkom takmer každej televízie, hoci nezriedka na úkor obsahovej kvality. Bolo by preto naivné predpokladat', že televízni tvorcovia a manažéri uprednostnia výsledky vedeckých štúdií a korešpondujúcich etických reflexií pred komerčnými a inými iniciatívami. Akútny nedostatok takých ,spoločenských inštitúcií, ktoré by boli schopné zabezpečit' efektívnu a dostatočne flexibilnú reguláciu“ (Hajko, 2017: 64) nielen mediálneho priestoru samotného, ale aj aplikovania nových technológií v živote jednotlivca a spoločnosti vo všeobecnosti, je vel'kým problémom súčasných spoločností. Napriek tomu, alebo skôr práve preto, sa treba pokúsit' inšpirovat' tvorcov mediálnych obsahov $\mathrm{k}$ takému postoju voči tvorbe obsahov daného média, u ktorých sa zníži pravdepodobnost', že zasiahnu do formujúcej sa identity adolescenta negatívnym spôsobom. Volanie po takejto „mediálnej zodpovednosti“ nie je napokon len akýmsi praktickým postulátom, ale vychádza z predstavy l'udskej zodpovednosti za využívanie l'ud'mi vytvorených technológií. (Kondrla - Repar, 2017: 22-23). Ak to aj nebude možné dosiahnut' apelom na zodpovednost' producentov kultivovat' želatel'né hodnoty u príjemcov mediálnych obsahov, stále je k dispozícii možnost' zámerného kultúrneho a spoločenského tlaku na tvorcov mediálneho obsahu produkovat' to, čo je 
z dlhodobejšieho hl'adiska pre spoločnost' prospešné. Zdôraznit' pritom treba aj opačnú stranu rovnice: médiá nie sú nepriatel'ským fenoménom voči výchove a vzdelávaniu. Mediálna výchova môže inšpirovat' k ich praktickému využitiu, viest' k osvojovaniu mediálnych kompetencií a k schopnosti kritického myslenia. Prijímatelia mediálnych obsahov $\mathrm{s}$ dostatočne vyvinutým kritickým myslením, vrátane schopnosti morálnej reflexie, môžu za istých okolností následne vytvorit' spomínaný spoločenský tlak (formou diváckeho dopytu aj kritickej spätnej väzby) na tvorcov mediálnych obsahov a tým spoluformovat' obsahovú štruktúru mediálneho priestoru. Ak však prijímatelia mediálnych obsahov ostanú na úrovni povrchných „estétov", túžiacich po zábave ako forme esteticko-existenciálneho naplnenia, budú odsúdení do pozície manipulovatel'ných (a manipulovaných) „divákov, ktorí nie sú schopní robit’ dôležité rozhodnutia." (Kralik - Tinley, 2017: 25) Dostanú sa tým nielen do nebezpečenstva hodnotovej a postojovej manipulácie, psycho-chemickej závislosti (Stefecek - Bravena - Mahrik, 2011: 213-215), ale aj sploštenia svojej dôstojnosti na úrovni zámerného utvárania identity, kultivácie slobody a hl'adania zmyslu svojho bytia. (Hanes - DeMuynck, 2017: 124). Kriticky analyzovat' treba zároveň subjektívnu aj kolektívnu skúsenost', že akcelerácia času v modernej dobe, spôsobená použitím moderných technológií (vrátane médií), nás paradoxne „doviedla ku chronickému nedostatku času“ a nenaplnila zaslúbenie „dobrého života“. (Klun, 2017: 9). Hoci podrobné skúmanie týchto kritických otázok ostáva za hranicou tejto štúdie, jej výsledky sú d’alším indikátorom, že im treba venovat' sústredenú pozornost'.

\section{Bibliographic references}

BURTON, G. - JIRAK, J. 2001. Uvod do studia medii. Praha: Barrister \& Principal. ISBN 80-85947-67-6.

DUCK, J. M. - HOGG, M. A. - TERRY, D. J. 1999. Social Identity and Perceptions of Media Persuasion: Are We Always Less Influenced Than Others? In: Journal of Applied Social Psychology [online], vol. 29, n. 9, p. 1879-1899 [cit. 2016-08-19]. Dostupné na internete: <http://www3.interscience.wiley.com/journal/119067643/ abstract?CRETRY=1\&SRETRY $=0>$.

ERIKSON, E. H. 1963. Childhood and Society. 2. vyd. New York: W.W. Norton \& Company, Inc. ISBN 0-393-31068-X.

GOFFMAN, E. 1990. On Cooling the Mark Out: Some Aspects of Adaption to Failure. In: HEEREN, J. W. - MASON, M. 1990. Sociology: Windows on Society. Los Angeles: Roxbury Publishing Company, p. 69-78. ISBN 0-935732-11-X.

HAJKO. 2017. Ethics and Science: Challenges and Possibilities. In: Komunikacie, vol. 19, n. 1, pp. 64-68. ISSN 1335-4205.

HANCOX, J. R. - MILNE, J. B. - POULTON, R. 2004. Association between Child and Adolescent Television Viewing and Adult Health: a Longitudinal Birth Cohort Study. In: The Lancet, Vol. 364, n. 9430, (17 July 2004 - 23 July 2004), p. 257-262.

HANES, P. - DE MUYNCK, B. Deification of Technology and the Dignity of the Human Person. In: Komunikacie, vol. 19, n. 1, pp. 121-125. ISSN 1335-4205.

JANKOVA, G. 2016. The socializing and educational function of media and marketing communication. European Journal of Science and Theology, vol. 12, n. 3, p. 93-100. ISSN 1841-0464.

JUROVA, J. 2017. Do the Virtual Communities Match the Real Ones? (Communitarian Perspective). In: Komunikacie, vol. 19, n. 1, pp. 14-18. ISSN 13354205 .

KACINOVA, V. 2006. Rozvoj medialnych kompetencii u 15-18 rocnych adolescentov a mozne sposoby ich rozvijania $\mathrm{v}$ ramci institucionalizovanej vyucby 
medialnej vychovy na strednych skolach. In: Adolescencia - aktualne otazky predcasneho a predlzeneho dospievania. Bratislava: Slovenska spolocnost pre rodinu a zodpovedne rodicovstvo, p. 109-120. ISBN 80-968891-5-X.

KLUN, B. 2017. Modern Technology's Effort to Master Time as a Challenge for Ethics. In: Komunikacie, vol. 19, n. 1, pp. 9-13. ISSN 1335-4205.

KONDRLA, P. - REPAR, R. 2017. Ontological Consequences of the Ethics of Technology. In: Komunikacie, vol. 19, n. 1, pp. 19-24. ISSN 1335-4205.

KRALIK, R. - TINLEY, S. J. 2017. Kierkegaard's Ethics as an Answer to Human Alienation in Technocratic Society. In: Komunikacie, vol. 19, n. 1, pp. 25-29. ISSN 1335-4205.

LUKSIK, I. - HRADILEKOVA, Z. 2000. Sociokulturny a rodovy rozmer volneho casu mladych ludi. In: Sociologicky prieskum ,ako vyuzivaju volny cas deti a mladez“. Bratislava: Rada mladeze Slovenska, Agentura socialnych analyz „ASA“, p. $40-55$.

MARSHALL, J. S. - GORELY, T. - BIDDLE, S. J. H. 2006. A descriptive epidemiology of screen-based media use in youth: A review and critique. In: Journal of Adolescence [online], vol. 29, n. 3, p. 333-349 [cit. 2016-08-06]. Dostupne na internete:

$<$ http://www.sciencedirect.com/science?_ob=ArticleURL\&_udi=B6WH0-

4HCMSK71\&_user=10\&_rdoc $=1 \& \_f m t=\& \_o r i g=$ search $\& \_s o r t=d \& \_d o c a n c h o r=\& v i$ ew $=$ c\&_searchStrId $=1002185773 \&$ _rerunOrigin $=$ google $\&$ acct $=$ C000050221\&_vers ion $=1 \&$ \&urlVersion=0\&_userid=10\&md5=ea2c0115cfb5c7ee204a63cfc03cbb67>.

MEAD, G. H. 1967. Mind, Self and Society. Chicago: University of Chicago Press. (1. vyd. Chicago, 1934). ISBN 0-226-51668-7.

MCQUAIL, D. 2007. Uvod do teorie masove komunikace. 3. vyd. Praha: Portal. ISBN 978-80-7367-338-3.

MIOVSKY, M. 2006. Kvalitativni pristup a metody v psychologickem vyzkumu. Praha: Grada Publishing. ISBN 80-247-1362-4.

MOTL, W. R. et al. 2006. Naturally occurring changes in time spent watching television are inversely related to frequency of physical activity during early adolescence. In: Journal of Adolescence [online], vol. 29, n. 1, p. 19-32 [cit. 2016-0806]. Dostupné na internete: $<$ http://www.sciencedirect.com/science?_ob=ArticleURL\&_udi=B6WH0-4FV9MJJ-

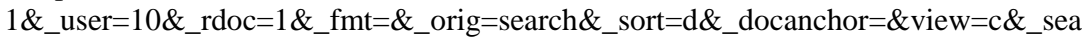
rchStrId=1002369653\&_rerunOrigin $=$ google\&_acct $=$ C000050221\&_version $=1 \&$ _url Version $=0 \& \_u s e r i d=10 \& \mathrm{md} 5=\mathrm{f} 34 \mathrm{ad0d} 5 \mathrm{~b} 2 \mathrm{e} 4 \mathrm{e} 241 \mathrm{~b} 98440888 \mathrm{f} 3462 \mathrm{ae}>$.

ONDREJKOVIC, P. 2004. Socializacia v sociologii vychovy. Bratislava: Veda. ISBN 80-224-0781-X.

PALA, G. 2015. The Family in Media Ciphers. In: European Journal of Science and Theology, vol. 11, n. 6, p. 45-56. ISSN 1841-0464.

PAVLIKOVA, M. 2017. Consciousness of Anxiety in Literary Work of Don DeLillo. In: XLinguae Journal, Vol. 10, n. 1, p. 62-69, ISSN 1337-8384.

SEDOVA, K. 2007. Deti a rodice pred televizi. Rodinna socializace detskeho televizniho divactvi. Brno: Paido - edice pedagogicke literatury. ISBN 978-80-7315149-2.

SLIVKA, D. - MIERZWA, J. 2017. Intentional Abuse of Social Networks with the Goal of Promoting Ideas of Anti-Semitism, Xenophobia, and Racism. In: Komunikacie, vol. 19, n. 1, p. 54-58. ISSN 1335-4205.

STEFECEK, J. - BRAVENA, N. - MAHRIK, T. 2011. Ethical Bridges: Interdisciplinary Insights into Ethical Challenges of Contemporary Philosophy, Theology and Technology. (Kierkegaard, Bonhoeffer and Nanotechnology). Toronto: Kierkegaard Circle. ISBN 978-0-9809365-6-8. 
SUCHY, A. 2007. Medialni zlo - myty a realita. 1. vyd. Praha: TRITON. ISBN 97880-7254-926-9.

TURCAN, C. 2017. Hans Jonas' Ethics of Technology: Risks of Technological Society. In: Komunikacie, vol. 19, n. 1, pp. 35-38. ISSN 1335-4205.

VALCOVA, K. - PAVLIKOVA, M. - ROUBALOVA, M. 2016. Religious Existentialism as a Coutnermeasure to Moralistic Therapeutic Deism. In: Komunikacie, vol. 18, n. 3, p. 98-104. ISSN 1335-4205.

VRABEC, N. 2008. Mladez a media: Medialna gramotnost mladých ludi na Slovensku. 1. vyd. [online]. Bratislava: IUVENTA - Slovensky institut mladeze. [cit.2016-09-10]. Dostupne na internete: $<$ http://www.iuventa.sk/index.php?www=sp_file\&id_item=628>. ISBN 978-80-8072074-2.

WARRING, D. V. 2008. Identity development: Engaging for Global Understanding in the Pursuit of Social Justice. In: M. ALAGIC - G.M. RIMMINGTON - F. LIU - K. GIBSON (Eds.). 5th International Conference on Intercultural Communication Competence. Kansas: College of Education, p. 155-176. ISBN 0-615-2071053995.

ZALEC, B. 2011. On Not Knowing Who We Are: The Ethical Importance of Transcendent Anthropology. In: Synthesis Philosophica, vol. 51, n. 1, pp. 105-115.

ZASȨPA, T. 2002. Media v case globalizacie. Bratislava: LUC. ISBN 80-7114-387-1. ZILKOVA, M. 2006. Globalizacne trendy v medialnej tvorbe. Nitra: FF UKF, ÚLUK. ISBN 80-8050-941-7.

Štúdia je čiastkovým výstupom projektu VEGA č. 1/0216/15 „Celebrity v sociálnej reklame a ich preferencia u adolescentov“ a čiastkovým výstupom projektu KEGA, 044UKF-4/2016 "Nanoetika" tvorba vysokoškolskej učebnice a webovej platformy pre I. a II. stupeň vysokoškolského štúdia.

Words: 4411

Characters: 31122 (17,29 standard pages)

PhDr. Andrea Lesková, PhD.

doc. PhDr. Michal Valčo, PhD.

Department of General and Applied Ethics

Faculty of Arts

Constantine the Philosopher University in Nitra

Hodzova 1, 94901 Nitra

Slovak Republic

aleskova@ukf.sk

mvalco@ukf.sk 